\title{
Salinity tolerance of northern Brazilian mangrove crab larvae, Ucides cordatus (Ocypodidae): Necessity for larval export?
}

Accepted for publication by Estuarine Coastal Shelf Science, March 2006

\section{Karen Diele ${ }^{1} \&$ Darlan J.B. Simith ${ }^{2}$}

${ }^{1}$ Corresponding author. Center for Tropical Marine Ecology, Fahrenheitstraße 6, 28359 Bremen, Germany. Fone: ++49 (0) 421 2380053, Fax: ++49 (0) 4212380053 , kdiele@zmt.uni-bremen.de

${ }^{2}$ Núcleo de Estudos Costeiros, Universidade Federal do Pará (UFPa), Campus Universitário de Bragança. simithdjb@hotmail.com

\section{Abstract}

The life cycle of the semi-terrestrial mangrove crab Ucides cordatus includes pelagic larvae that are released into estuarine waters during the wet season and who may thus encounter potentially stressful low and variable salinity conditions. The effect of salinity on the survival of the zoea larvae, the number of zoeal stages and the duration of development from hatching to megalopa was experimentally studied by rearing larvae from the Caeté estuary, $\mathrm{N}$-Brazil, in seven salinity treatments $(0,5,10,15,20,25$, and 30$)$. For a better interpretation of the laboratory results, estuarine salinities were measured over five consecutive years during the species' reproductive season. The survival of the zoea larvae varied significantly with salinity, while the number of stages and the duration of their development remained 
constant. Development to megalopa took $20.77 \pm 1.57$ days and comprised five zoeal stages with ZI and ZII being euryhaline and later stages stenohaline. The newly hatched larvae stayed alive for up to six days in freshwater (average $4.32 \pm 0.82$ days), but did not moult to the second zoeal stage. ZII larvae first occurred from salinity 5 onwards and later zoeal stages at all tested salinities $\geq 10$. However, the larvae only survived to megalopa at salinities $\geq 15$, with highest numbers at salinity $30(72 \%)$ and lowest at $15(16 \%)$. Lethal salinities $\leq 10$ occurred frequently in the estuary during the reproductive season. This suggests a need for larval export to offshore and thus more saline waters to allow for significant larval survival and maintenance of viable populations of this commercially important species. A regional rather than local approach for management is suggested due to the likelihood of long distance larval dispersal by off-shore currents.

Key words Ucides cordatus, mangrove crab, salinity tolerance, larval development, export, connectivity, North Brazil

\section{Introduction}

Salinity is considered an ecological key factor in estuarine and coastal zones that are characterized by a high variability in this parameter (Anger 2003). While juvenile and adult crabs of estuarine and semi-terrestrial species are generally well adapted to the wide range of salinities in their habitat, their pelagic larvae are often sensitive towards varying and extreme salinity conditions (Sastry, 1983; Charmantier, 1998, Charmantier et al., 2002). The salinity tolerance of the larvae varies between species, usually indicating whether the larvae develop within estuaries (retention strategy: e.g. Rhithropanopeus harrisii: Costlow et al., 1966; Cronin, 1982; Helice leachi: Mia and Shokita, 2002), or off-shore (export strategy: e,g, Uca pugnax: O’Connor and Epifanio, 1985; Sesarma angustipes: Anger et al., 1990;

Chasmagnathus granulata: Charmantier et al., 2002; Armases rubripes: Luppi et al., 2003). 
Thus, the ecology of estuarine and semiterrestrial brachyurans with meroplanktonic larvae can be better understood by investigating the salinity tolerance of the latter. The present study focuses on Ucides cordatus cordatus (Linnaeus, 1763) (hereafter referred to as $U$. cordatus), a large commercially exploited ocypodid crab which occurs in mangrove forests along the subtropical and tropical Atlantic coast of the Americas (Türkay, 1970). In many regions of Brazil crabs are threatened by habitat destruction, diseases and fishery (Nordi, 1994; Botelho et al.; 2000, Alves et al., 2005; Boeger et al., 2005). In our study area, 320 km southeast of the Amazon mouth, the local Ucides population is still comparably healthy (Glaser and Diele, 2004; Diele et al., 2005), but fishing pressure is increasing due to demographic growth and adequate management strategies are currently being discussed. The crabs have a strong impact on litter turnover and nutrients cycling in this mangrove ecosystem (Nordhaus et al., in press). They reproduce in the wet season between January and June (Diele, 2000) when estuarine salinities are often low and fluctuating. Adult and juveniles survive long exposures to freshwater (> 3 weeks, Diele, unpublished), but the salinity tolerance of the larvae is not well known. In south-western Brazil Rodriguez and Hebling (1989) cultivated larvae in water with a constant salinity of 24. Survival from hatching to megalopa was $75 \%$ and the development comprised 5 to 6 zoeal stages.

In this paper we investigate the tolerance of $U$. cordatus zoea larvae towards a wide range of salinities ( 0 to 30 ) in order to evaluate their survival potential in mangrove estuaries and in offshore waters of Northern Brazil. Our specific objectives were to determine the effect of salinity on the survival of the larvae, the number of larval stages and the duration of larval life until the megalopal stage. The results of the laboratory study are compared with field data on estuarine salinities and discussed in the context of larval retention versus larval export strategy. Finally, the likely implication of the findings for management of $U$. cordatus in Northern Brazil and for configuring coastal reserves is outlined. 


\section{Materials and methods}

\subsection{Study area and field measurements}

The Caeté estuary is located about $320 \mathrm{~km}$ southeast of the mouth of the Amazon river in Northern Brazil (Figure 1) and is part of the second largest continuous mangrove area of the world (Kjervfe and Lacerda, 1993). Its western shore is formed by a peninsula cut by numerous creeks and channels. Approximately $140 \mathrm{~km}^{2}$ of the Caeté peninsula is covered with mature mangrove forests densely populated by crabs, Ucides cordatus and fiddler crabs (Uca spp.) being the most abundant ones (Koch and Wolff, 2002; Diele et al., 2005; Koch et al., 2005). The region is characterized by semidiurnal macro tides with up to $5 \mathrm{~m}$ amplitude during the spring tide period. Due to the dynamic tidal regime and shallow water ( $10 \mathrm{~m}$ at high tides even at the mouth), the Caeté estuary is well mixed (Dittmar, 1999). As a consequence variations in salinity and temperature between surface and bottom waters are absent or small (Dittmar, 1999; Diele, pers. observations). Mean annual rainfall is about $2500 \mathrm{~mm}$ and occurs mostly during the wet season from January to June while average water $\left(27-30^{\circ} \mathrm{C}\right)$ and air temperatures $\left(24-28^{\circ} \mathrm{C}\right)$ vary little over the year (MADAM unpublished. data).

In the present study we measured the salinity at four tidal creeks and channels and at the beach along a transect running from the upper and lower estuary to the northern shore of the peninsula (Figure 1). Subsurface water samples were taken weekly between January and June from 2001 to 2005 (beach: $2002-2005$ ). The salinity of the samples was measured with a WTW-LF 197 using the Practical Salinity Scale.

\section{(Insert Figure 1)}




\subsection{Cultivation of the larvae}

1000 I water with a salinity of 20 was obtained $35 \mathrm{~km}$ offshore for the cultivation experiments. The water was filtered (Eheim and Diatom filter, $1 \mu \mathrm{m})$; sodium chlorate $(2.5 \%)$ added ( $2 \mathrm{ml}$ per I seawater) and stored in $500 \mathrm{I}$ tanks with constant aeration. For gaining adequate salinities for the experimental treatments deionised water was used for dilution and artificial salt (Corolife) for concentration.

Preliminary tests have shown that the larvae from different females respond similarly to low and high salinities (Diele 2000; Simith \& Diele, pers. observation) and in the present study sibling larvae were used for the laboratory cultivation experiments. The larvae were obtained from an ovigerous female captured in the northern mangroves of the Caeté peninsula (near Furo Grande, see Figure 1, ambient estuarine salinity was 20). The female was kept in a 15 I aquaria in filtered offshore water (see above) until it released its larvae a day later. Immediately after their release, the larvae were transferred to $100 \mathrm{ml}$ plastic vials ( 5 and 8 $\mathrm{cm}$ diameters at bottom and top, respectively). Seven treatments with salinity $0,5,10,15$, 20, 25 and 30, in the following nominated T0, T5, T10, etc., were run and per treatment 50 larvae were individually cultivated. Water temperature in the cultivation vials was $26.64 \pm$ $1.09^{\circ} \mathrm{C}$ (Stow Away Tidbit temperature logger, Onset Computer corporation) and the light regime was $12: 12 \mathrm{~h} \mathrm{~L}: \mathrm{D}$. The larvae were fed daily with planktonic microalgae (Dunaliella salina) and freshly hatched Artemia salina naupli, both food items known to significantly enhance the survival of cultivated $U$. cordatus larvae (Abrunhosa et al., 2002). Every 3 to 5 days the water in the cultivation vials was changed. The status of the larvae was checked daily and deaths or moulting events noted. On day 35 of the cultivation all formerly viable megalopae were killed when water with salinity $~ 70$ was accidentally added to their cultivation vials during water change. 


\subsection{Statistical analysis}

Survival data were analysed by contingency tables $(\mathrm{R} \times \mathrm{C})$, followed by $\mathrm{Chi}^{2}$ tests. After testing for normality (Shapiro-Wilk) and variance homogeneity (Levene) the data on development duration were tested by multiple or pair wise nonparametric statistics (KruskallWallis and Mann-Witney- $U$, respectively).

\section{Results}

\subsection{Salinity measurements}

Salinity varied between 0 and 39 during the wet season with increasing values from the upper estuary (FT) to the beach (PA) (Figure 2). Salinities were generally highest in January and lowest in March and April. At the upper estuarine study site, FT, salinities $\leq 10$ ("lethal" salinities, see section 3.3) were recorded throughout the entire wet season in all years. At the central and lower estuarine sites (FO, FC, FG) salinities $\leq 10$ occurred in February, March and April in three to four of the five study years (Figure 3). At the beach lethal salinities were encountered in March and April only, in one and two of the four study years, respectively.

(Insert Figure 2)

(Insert Figure 3) 


\subsection{Larval survival}

Survival from hatching to megalopa varied between salinity treatments. No larvae developed to megalopae in T0, T5 and T10 (Figure 4). In T15 $16 \%$ of the zoea larvae reached the megalopal stage, which was distinctly less than in treatments with higher salinities $(p<$ 0.0001). Survival to megalopa did not differ much between T20 and T25, but in T20 (52 \%) it was significantly lower than in T30, where $72 \%$ of all larvae reached the megalopal stage ( $p$ $<0.05$ ) (Figure 4).

The zoeal phase comprised five stages (ZI to ZV) irrespective of salinity ( $\geq 15)$. However, differences among salinity treatments were observed concerning the survival of the larvae (Figure 4). While ZI larvae died in freshwater (T0), they moulted to the second stage in all other salinity treatments. In T5 $64 \%$ of the ZI larvae already survived, however significantly more $(90 \%)$ moulted to ZII in the more elevated salinities $(p<0.05)$ (Figure 4$)$. In contrast to the first larval stage, ZII, ZIII and ZIV larvae died not only in T0 but also in T5. The survival of ZII larvae in T10 and T15 was 72\% and 78\%, respectively, and was even higher in T20, T25 and T30 where over $90 \%$ reached the subsequent larval stage. In ZIII and ZIV survival in T10 was only $\leq 25 \%$, which was distinctly lower than in most other salinity treatments $(p<$ 0.05) (Figure 4). In ZIII survival rates did not differ between T20, T25 and T30 whereas in ZIV significantly more larvae survived in T30 than in all other treatments $(p<0.05)$. In contrast to the first four zoeal stages, V larvae did not survive in T10. In T15 67\% already survived, but this was still significantly less than in T25 and T30 (97\%, p<0.05). Survival in T20, T25 and T30 was similar in this final zoeal stage (Figure 4).

(Insert Figure 4) 


\subsection{Development duration}

Development from hatching to megalopa took between 18 and 27 days and did not differ between salinity treatments (Figure 5$)(p<0.05)$. Average duration was $20.77 \pm 1.57$ days (pooled data). Despite total mortality in freshwater, ZI larvae still survived up to six days in T0 with an average of $4.32 \pm 0.82$ days (Figure 5). In the other treatments the duration of the ZI stage ranged between $3.5 \pm 0.54$ days in T10 and $3.72 \pm 1.99$ days in T30 (Figure 5). ZII larvae lived an average of $3.72 \pm 1.99$ days in T5 before they died. The development duration of this zoeal stage decreased with increasing salinities and was over a day shorter in T30 when compared to T10 (3.52 \pm 0.63 versus $4.83 \pm 1.08$ days, respectively, $\mathrm{p}<$ 0.0001). In ZIII, significant differences in development time were observed between T10 and T20 (4.63 \pm 0.74 versus $3.80 \pm 0.79$, respectively, $p<0.05$ ) (Figure 5). The two ZIV larvae that had survived the T10 treatment moulted to ZV after five days, which was approximately a day longer than in T20 and T25 ( $<0.05)$, but died shortly after moulting. Development duration of ZV larvae to megalopa was similar in all salinities $(\geq 15)$ and took $5.05 \pm 0.54$ days at an average (Figure 5).

\section{(Insert Figure 5)}

Development and survival curves of the larvae at each salinity through successive zoeal stages until megalopa are presented in Figure 6 and agree with the data shown above. The results can be summarized as follows: (1) Salinities $\leq 10$ represent lethal conditions as they do not allow development to megalopa. (2) In freshwater newly hatched ZI larvae survive up to six days. (3) In salinity 5 first ZII larvae appeared but by day 10 all were dead without having moulting to ZIII (4) In salinity 10 survival until ZIII was high but only few larvae reached zoeal stage IV and V. (5) In T15 some larvae developed to megalopa, however 
survival beyond ZIII was low. (6) Salinity 20, 25 and 30 represent suitable conditions for all zoeal stages with similar development pattern and survival. Salinity 30 appears optimum due to highest survival.

\section{(Insert Figure 6)}

\section{Discussion}

In many brachyuran species salinity affects the survival of their larvae $\left(\mathrm{O}^{\prime}\right.$ Connor and Epifanio, 1985; Anger, 1991; Islam et al., 2002; Luppi et al., 2003) and often also the duration of their development, which is generally prolonged under osmotic stress (e.g. O'Connor and Epifanio, 1985; Gonçalves et al., 1995; Anger, 1996; Luppi et al., 2003). In low salinities larval development may not only take longer, but also comprise an additional larval stage, as e.g. in the Chinese mitten crab Ericocheir sinensis (Anger, 1991) and in the estuarine crab Chasmagnathus granulata (Giménez 2003; Giménez and Anger, 2003). In our study the survival of $U$. cordatus larvae increased distinctly with salinity ( 4.5 fold higher values in T30 than in T15), however, neither the duration of development to megalopa nor the number of zoeal stages of the larvae differed between treatments. All larvae developed via five zoeal stages (see also below) and the few ones surviving to megalopa at salinity15 did not suffer a significant temporal delay in development, when compared to those reared at salinity 30 . Hence, development duration and morphogenesis appear to be independent of osmotic stress when minimum salinity conditions are met that allow survival to megalopa.

Assuming that Ucides larvae are exported from estuarine to coastal waters (see below), the ability to develop similarly in both intermediate and high salinities (15 and 30, respectively) could be an adaptive trait: salinities fluctuating between 15 and 30 can still be encountered many tens of kilometres offshore in the upper layers of the water column during the north 
Brazilian wet season (Diele, personal observation). Uncoupling development duration from fluctuations within this salinity range may be one factor aside others that allows to synchronize megalopal appearance with the tidal neap-spring cycle. U. cordatus megalopae were particular abundant in plankton net-samples taken at spring tides (Diele, 2000; Diele unpublished), and high megalopa numbers at spring tides were also observed in many other estuarine crab species (van Montfrans et al., 1990; van Montfrans et al., 1995; Morgan and Christy, 1995; Christy and Morgan, 1998; Paula et al., 2001). This suggests that estuarine immigration by megalopae is facilitated by high amplitude tides and hence that timing of development plays an important role for successful recruitment.

The U. cordatus larvae were cultivated individually in the present study, and development always encompassed five zoeal stages. However, this number can vary: while sibling larvae from other females of the Caeté crab population also developed via five stages when reared individually, an additional sixth stage occurred when larvae of the same broods were reared in groups (Simith \& Diele, personal observation). In mass cultivations of larvae from a southwestern Brazilian crab population the development of $U$. cordatus also comprised six zoeal stages (Silva, pers. comm). Thus, environmental factors such as competition for space or food appear to be the reason for the reduced number of zoeal stages in individually versus mass-cultivated larvae. Further experiments will investigate the extent to which the number of larval stages is plastic as opposed to genetically determined. Development of $U$. cordatus can also encompass an additional zoeal stage when specimens are reared individually, as shown by Rodriguez and Hebling's study (1989), where $91 \%$ of the larvae developed via ZVI (salinity $24,25 \pm 1^{\circ} \mathrm{C}$ ). The average development duration until the megalopal stage was 36.51 days in their cultivation, instead of 20.77 days in our. These variations may have been caused by different diets. Whereas Rodriguez and Hebling fed their larvae with Artemia salina nauplii only, we provided a combination of $A$. salina and microalgae, which is more favourable (Abrunhosa et al., 2002, Abrunhosa unpublished). A flexible developmental path with a reduced number of zoeal stages and development time 
under better nutritional conditions would be advantageous for several reasons. In crustaceans, late premoult, ecdysis and early post-moult are very sensitive phases where larval mortality rates generally increase (Anger 2003). Skipping a larval stage can thus enhance survival. Furthermore, the risk of predation and physical stress in the pelagic environment is reduced when larval development is abbreviated (Morgan, 1995).

In the present study the $U$. cordatus larvae only survived to megalopa from salinity 15 onwards, confirming the pattern observed in other tests with larvae from the Caeté crab population (Diele 2000, Simith \& Diele, pers. observ.). Lethal salinities $\leq 10$ that inhibit larval development occur frequently in northern Brazilian mangrove estuaries during the wet season. In the upper Caeté estuary average monthly salinities were lethal throughout the entire wet season in all five study years, and in the central and lower part salinities $\leq 10$ occurred in February, March and April in three to four out of five study years. These are the months of peak reproductive activity of $U$. cordatus (Diele, 2000) and retention of the zoea larvae in the estuary would thus result in significant mortalities in most years. It seems contradictive that a species whose larvae die in low saline waters concentrates its reproduction on exactly those few months of the year, when precipitation is highest and salinity lowest. However, due to the differential response of the earlier and later zoeal stages to different salinities, the Caeté crab population seems to be well adapted to life in coastal Northern Brazil: The ZI larvae are extremely euryhaline as they may survive up to six days in freshwater, and can also cope with a wide range of salinities (62\% survival to ZII in T5 and > 80 $\%$ in T10 to T30). ZII larvae are also euryhaline (> $70 \%$ survival to ZIII from salinity 10 onwards) when compared to the increasingly stenohaline response of the subsequent larval instars. The variation in salinity tolerance of the earlier versus later zoeal stages is most probably based upon changes in their capacity to osmoregulate, from temporarily high in $\mathrm{ZI}$ to low in later zoeae, as is the case in other species (for review see Charmantier, 1998; Anger and Charmatier, 2000; Charmantier et al., 2002) 
Our findings suggest that viable crab populations can only be maintained if the larvae develop in more saline waters were significant numbers can survive. Hence, an export of the larvae by ebb currents from the estuary to coastal or oceanic waters seems to be a necessity in the life cycle of $U$. cordatus in Northern Brazil, in contrast to species with retention strategy, whose larvae are better adapted to low salinities (e.g. Rhitropanopeus harrisii: Cronin, 1982; Armases miersii: Anger, 1996). Larval export is common in many estuarine brachyurans and is generally interpreted as an avoidance of stressful salinities and or high densities of estuarine predators (Christy and Stancyk, 1982; Morgan, 1990; Anger et al.,1994; Morgan, 1995; Charmantier et al., 2002). In U. cordatus, the cumulative duration of the euryhaline $\mathrm{ZI}$ and $\mathrm{ZII}$ stages was $7.74 \pm 0.31$ days, a time span that seems long enough for ensuring that currents transport the larvae sufficiently off-shore. Field data from our study area give additional indication for the larval export strategy as only newly hatched zoeae were encountered in plankton samples from the lower Caeté estuary (Diele, 2000). The presence of megalopae in the same samples suggests that they resemble the ZI larvae in their tolerance of hypo-osmotic stress, allowing them to immigrate into estuaries. This will be tested in future experiments. Furthermore, the impact of pre-hatching salinities during embryogenesis on later survival and development should be studied, as well as the larvae's capacity for acclimation throughout their development (see Giménez and Anger, 2003). This will complement our understanding of how $U$. cordatus larvae cope not only with low, but also with fluctuating salinities throughout their development.

In contrast to the larval retention strategy, exported brachyuran larvae may be dispersed away from their parental estuary and settle in other estuaries (e.g. Scheltema, 1986; Botsford et al., 1989; Underwood and Fairweather, 1989; Anger et al., 1994, Shanks et al., 2003). In commercially exploited species the question whether local crab assemblages, e.g. $U$. cordatus of the Caeté peninsula, are strongly influenced by regional factors, e.g. the reproductive output of crabs from other peninsulas, is important for defining management strategies and the size of coastal reserves. Our results clearly point toward the larval export 
strategy and for determining the likelihood of population networks we are presently investigating the offshore dispersal of Ucides larvae along the North Brazilian coast. While the juvenile and adult crabs of each of the numerous mangrove peninsulas of the North Brazilian coastline are probably spatially separated by the rivers that deeply dissect the coast up to $40 \mathrm{~km}$ inland (Figure 1), the geomorphologic isolation of the benthic stage in the life cycle of $U$. cordatus can be overcome by common offshore larval pools. Connectivity of $U$. cordatus by larval migration is also currently studied by population genetics (Ewald et al., unpublished). Even though the spatial extension of the Ucides population is not yet delineated, we already now precautionary suggest a regional rather than local scale for management and conservation. Management of this fisheries resource is a central issue: over 1000 tons of crabs are annually harvested in the Caeté estuary (Diele et al., 2005; Araújo unpublished) and extractive reserves are currently being implemented in the study area. If recruitment of the Caeté crab population depends upon larvae originating from other, possibly distant estuaries, a management strategy focussing only upon the Caeté mangroves or adjacent peninsulas may be insufficient for ensuring the sustainability of the local crab fishery.

\section{Acknowledgements}

We thank Tárcio Soares for help in the laboratory, Heinfried Pohl for salinity measurements and the reviewers for their useful comments. This study was part of the MADAM project, a Brazilian-German cooperation financed by the Brazilian National Research Council (CNPq) and the German Ministry for Education and Research (BMBF) under the code 03F0154A. This is MADAM contribution No. 95. 
Figure 1
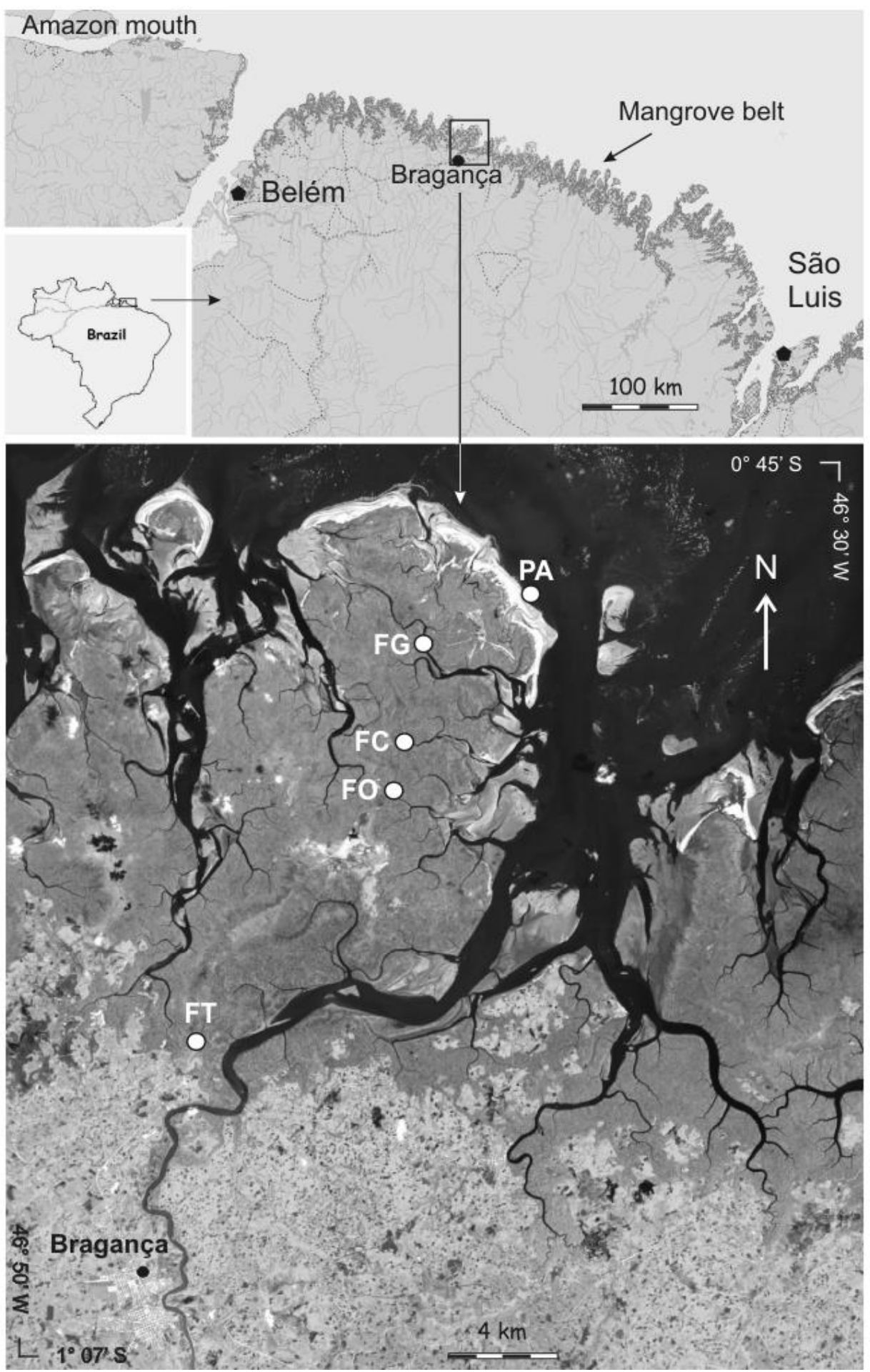

Figure 2 

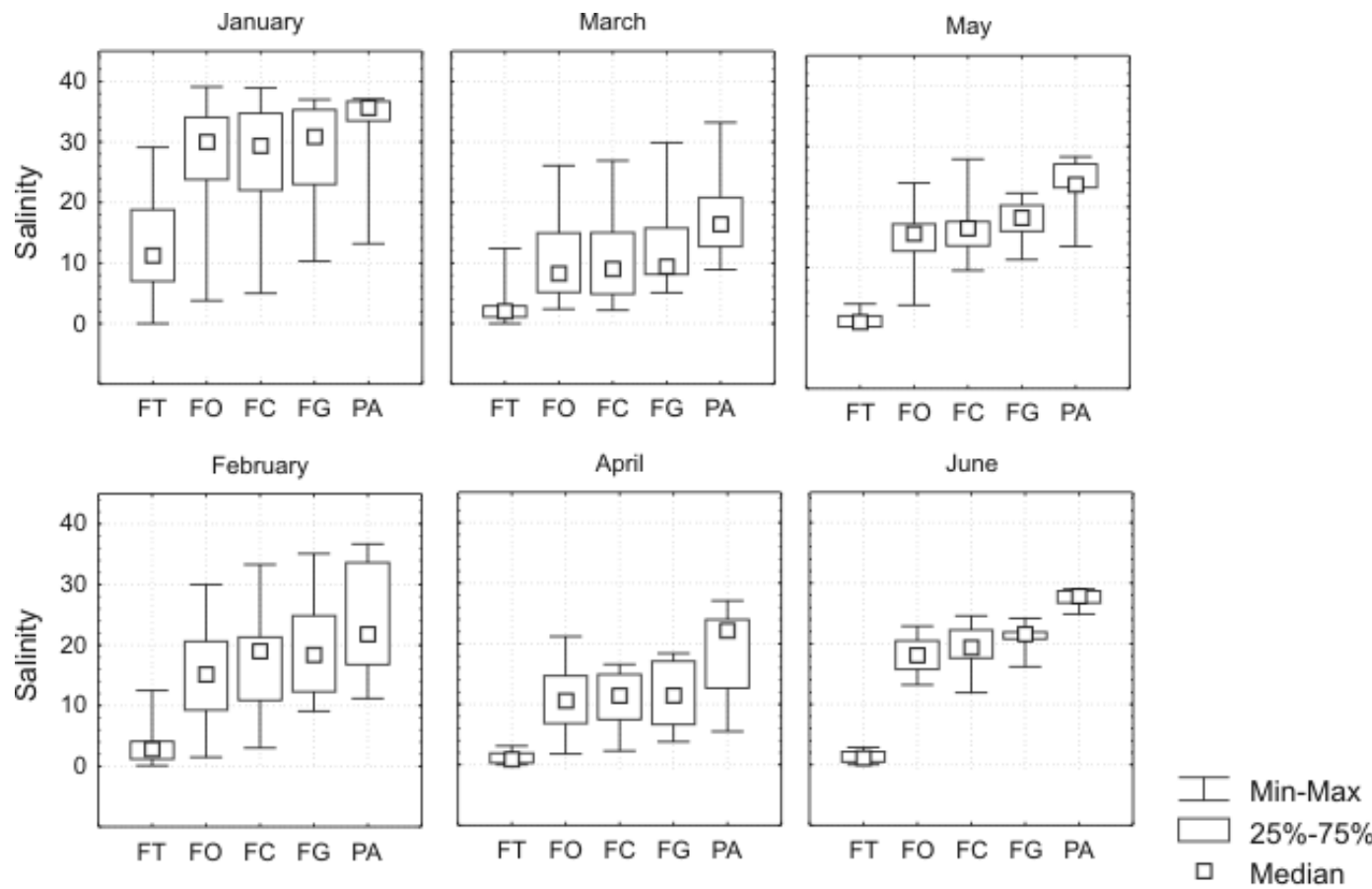

Station

Figure 3

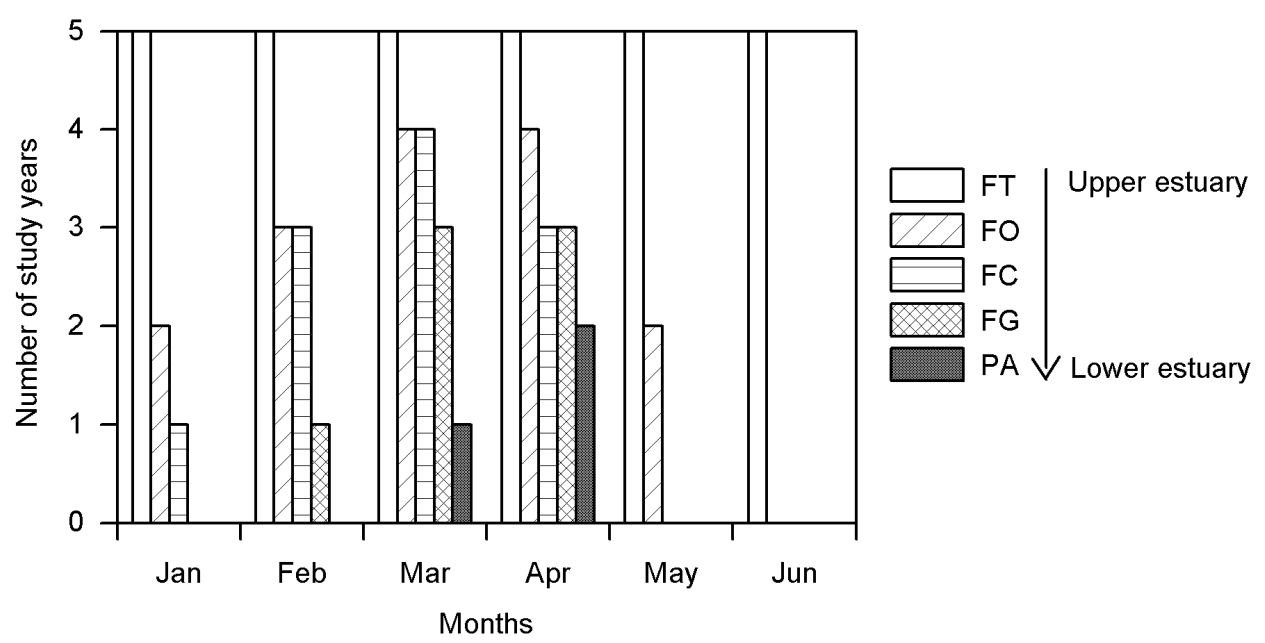

Figure 4 

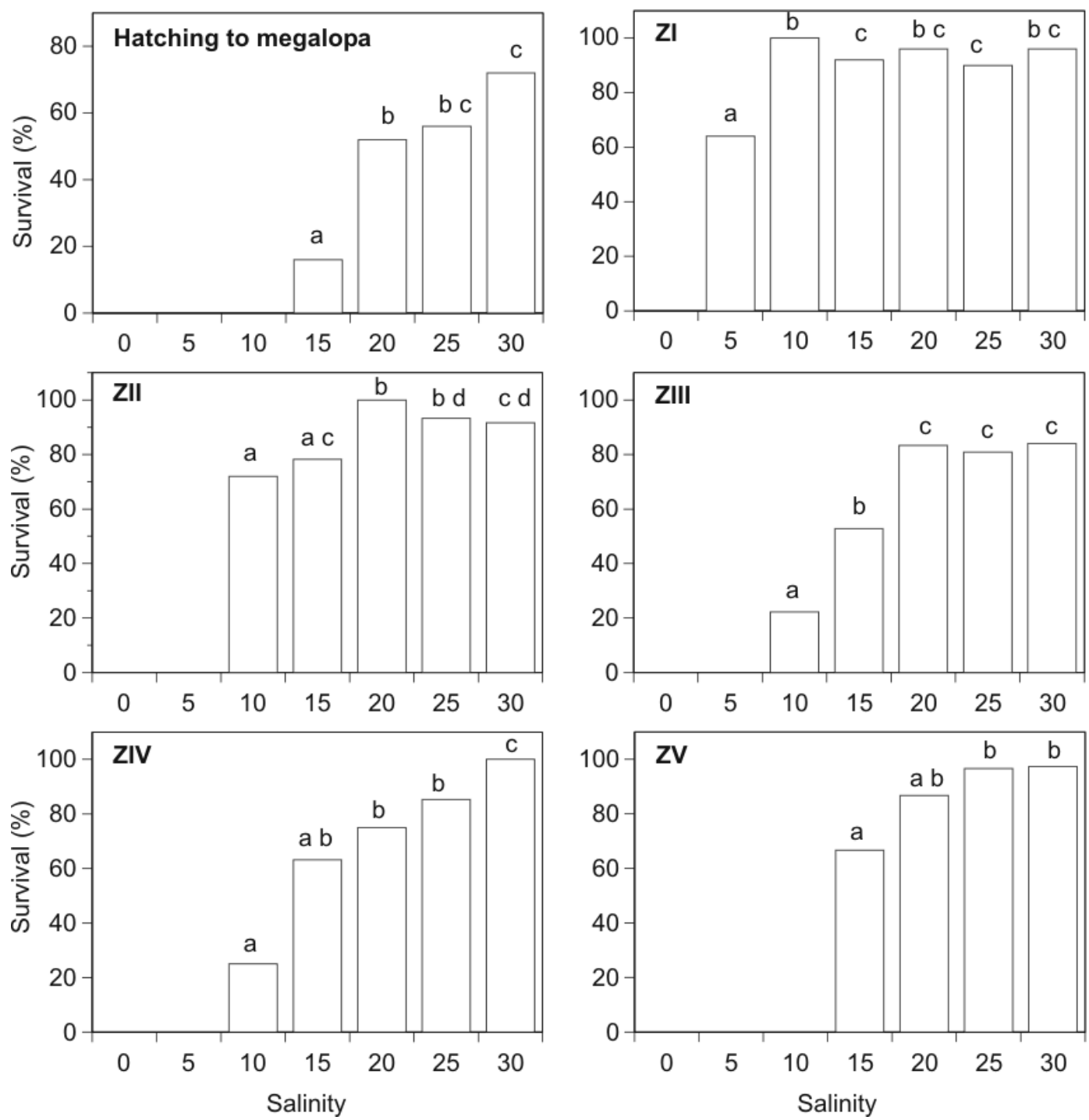

Figure 5 

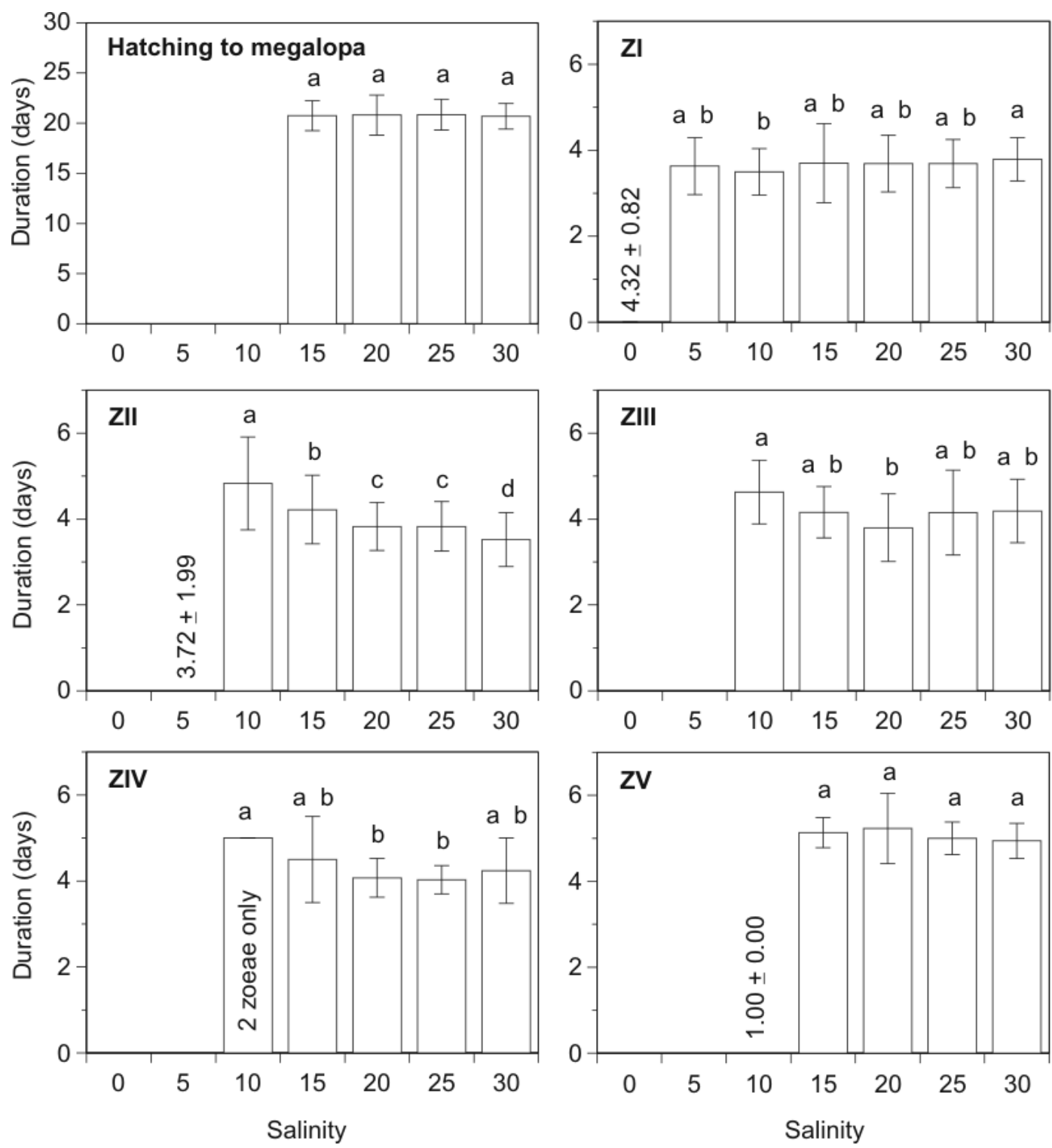

Figure 6 

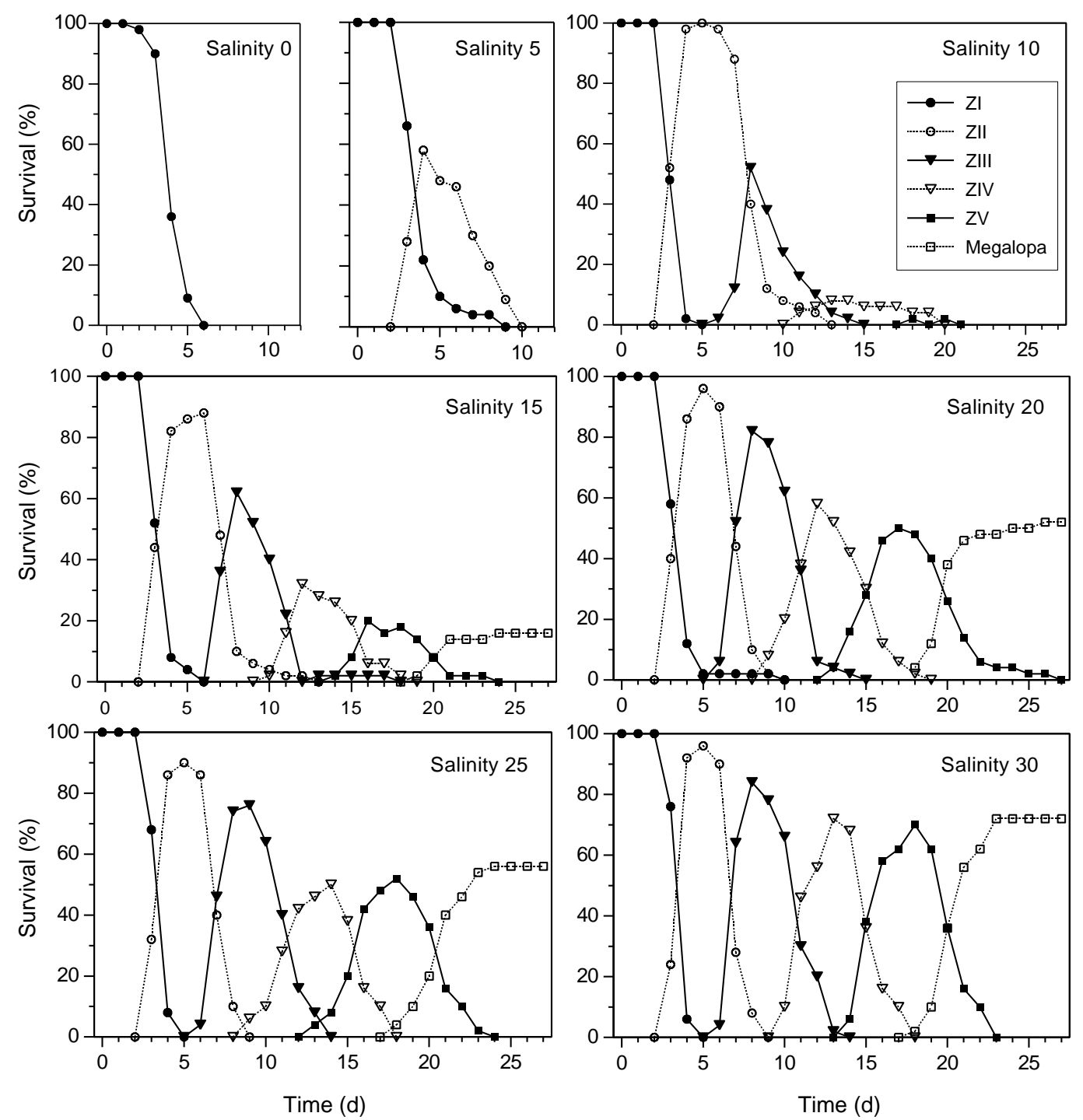

\section{References}

Abrunhosa, F.A, Silva-Neto, A.A., Melo, M.A., Carvalho, L.O., 2002. Importance of the food and feeding in the first larval stage of Ucides cordatus cordatus (Linnaeus, 1763)

(Decapoda: Ocypodidae). Article in written in Portuguese. Revista Ciência Agronômica 33: 5-12. 
Alves, R.R.N., Nishida, A.K., Hernández, M.I.M., 2005. Environmental perception of gatherers of the crab "caranguejo-uçá (Ucides cordatus, Decapoda, Brachyura) affecting their collection attitudes. Journal of Ethnobiology and Ethnomedicine 1:10.

http://www.ethnobiomed.com/content/1/1/10

Anger, K., 1991. Effects of temperature and salinity on the larval development of the Chinese mitten crab Eriocheir sinsensis (Decapoda: Grapsidae). Marine Ecology Progress Series 72, 103-110.

Anger, K., 1996. Salinity tolerance of the larvae and first juveniles of a semiterrestrial grapsid crab, Armases miersii (Rathbun). Journal of Experimental Marine Biology and Ecology 202, 205-223.

Anger, K., 2003. Salinity as a key parameter in the larval biology of decapod crustaceans. Invertebrate Reproduction and Development 43, 29-45.

Anger, K., Harms, J., Montú, M, de Bakker, C., 1990. Effects of salinity on the larval development of a semiterrestrial crab, Sesarma angustipes (Decapoda: Grapsidae). Marine Ecology Progress Series 62, 89-94.

Anger, K., Spivak, E., Bas, C., Ismael, D., Luppi, T., 1994. Hatching rhythms and dispersal of decapod crustacean larvae in a brackish coastal lagoon in Argentina. Helgoland Marine Research 48, 445-466.

Anger, K. and Charmantier, G., 2000. Ontogeny of osmoregulation and salinity tolerance on a mangrove crab, Sesarma curacaoense (Decapoda: Grapsidae). Journal of Experimental Marine Biology and Ecology 251, 265-274. 
Boeger, W.A., Pie, M.R., Ostrensky, A., Patella, L., 2005. Lethargic crab disease:

multidisciplinary evidence supports a mycotic etiology. Memórias do Instituto Oswaldo Cruz $100,161-167$.

Botelho, E.R., Santos, M.C.F., Pontes, A.C.P., 2000. Algumas considerações sobre o uso da redinha na captura do caranguejo-ucá, Ucides cordatus (Linnaeus, 1763), no litoral sul de Pernambuco-Brasil. Boletim Técnico cientifico do Cepene 8, 55-71.

Botsford, L.W., Armstrong, D.A., Shenker, J.M., 1989. Oceanographic influences on the dynamics of commercially fished populations. In: Landry, M.R. and Hickey, B.M. (Eds.), Coastal oceanography of the Pacific Northwest., Elsevier, the Netherlands, pp. 511-565.

Charmantier, G., 1998. Ontogeny of osmoregulation in crustaceans: a review. Invertebrate Reproduction and Development 33, 177-190.

Charmantier, G., Giménez, L., Charmantier-Daures, M., Anger, K., 2002. Ontogeny of osmoregulation, physiological plasticity and larval export strategy in the grapsid crab Chasmagnathus granulata (Crustacea, Decapoda). Marine Ecology Progress Series 229, 185-194.

Christy, J. and Stancyk, S.E., 1982. Adaptive significance of semilunar cycles of larval release in fiddler crabs (Genus Uca): Test of a hypothesis. Biological Bulletin 163, 251-263.

Christy, J.H. and Morgan, S.G., 1998. Estuarine immigration by crab postlarvae: mechanisms, reliability and adaptive significance. Marine Ecology Progress Series 174, 51 65. 
Costlow, J.D., Bookhout, C.G., Monroe, R., 1966. Studies on the larval development of the crab Rhitropanopeus harrisii (Gould). I. The effect of salinity and temperature on larval development. Physiological Zoology 39, 81-100.

Cronin, T.W., 1982. Estuarine retention of larvae of the mud crab Rhitropanopeus harrisii. Estuarine Coastal Shelf Science 15, 207-220.

Diele, K., 2000. Life history and population structure of the exploited mangrove crab Ucides cordatus cordatus (L.) (Decapoda: Brachyura) in the Caeté estuary, North Brazil. Center for Tropical Marine Ecology Contribution 9, ZMT Bremen, 103 pp.

Diele, K., Koch, V., Saint-Paul, U., 2005. Population structure, catch composition and CPUE of the artisanally harvested mangrove crab Ucides cordatus: Indications for overfishing? Aquatic Living Resources 18, 169-178.

Dittmar, T. 1999. Outwelling of organic matter and nutrients from a mangrove in North Brazil: evidence from organic tracers and flux measurements. Center for Tropical Marine Ecology Contribution 5, ZMT, Bremen, 229 pp.

Glaser, M. and Diele, K., 2004. Asymmetric outcomes: Assessing central aspects of the biological, economic and social sustainability of a mangrove crab fishery, Ucides cordatus (Ocypodidae), in North Brazil. Ecological Economics 49, 361-373.

Giménez, L., 2003. Potential effects of physiological plastic responses to salinities on population networks of the estuarine crab Chasmagnathus granulata. Helgoland Marine Research 56, 265-273. 
Giménez, L. and Anger, K., 2003. Larval performance in an estuarine crab, Chasmagnathus granulata, is a consequence of both larval and embryonic experience. Marine Ecology Progress Series 249, 251-264.

Gonçalves, F., Ribeiro, R., Soares, A.M.V.M., 1995. Laboratory studies of temperature and salinity on survival and larval development of Rhitropanopeus harrisii. Marine Biology 121(4), 639-645.

Islam, M.S., Shokita, S., Naruse, T., 2002. Effects of salinity on the larval development of the semi terrestrial sesarmid mangrove crab Neosarmatium indicum (A. Milne Edwards) under laboratory conditions. Crustacean Research 31, 1-8.

Kjervfe, B. , Lacerda, L.D., 1993. Management and status of the mangroves in Brazil. In: Lacerda, L.D. (Ed.), Conservation and sustainable utilization of mangrove forests in Latin America and Africa regions, Part 1: Latin America. ISME Mangrove Ecosystems Technical Reports, Okinawa, Japan, pp. 254-272.

Koch, V., Wolff, M., Diele, K., 2005. Comparative population dynamics of four fiddler crabs (Ocypodidae, genus Uca) from a North Brazilian mangrove ecosystem. Marine Ecology Progress Series 291, 177-188.

Koch, V. and Wolff, M., 2002. Energy budget and ecological role of mangrove epibenthos in the Caeté estuary, North Brazil. Marine Ecology Progress Series 228, 119-130.

Lara, R. J., 2003. Amazonian mangroves - a multidisciplinary case study in Pará state, North Brazil: Introduction. Wetlands Ecology Management 11, 217-221.

Luppi, T.A., Spivak, E.D., Bas, C.C., 2003. The effects of temperature and salinity on larval development of Armases rubripes Rahtbun, 1897 (Brachyura, Grapsioidea, Sesarmidae), 
and the southern limit of its geographical distribution. Estuarine Coastal Shelf Science 58, 575-585.

Mia, M.D.Y. and Shokita, S., 2002. Early life history of an estuarine grapsid crab, Helice leachi Hess. Indian Journal of Fisheries 49, 23-28.

Morgan, S.G., 1990. Impact of planktivorous fishes on dispersal, hatching and morphology of estuarine crab larvae. Ecology 71, 1639-1652.

Morgan, S.G., 1995. Life and death in the plankton: larval mortality and adaptation. In: McEdward, L.R. (Ed.), Ecology of marine invertebrate larvae. CRC press, Boca Raton, FL., pp. 279-321.

Morgan, S.G. and Christy, J.H., 1995. Adaptive significance of the timing of larval release by crabs. American Naturalist 145, 457-479.

Nordhaus, I., Wolff, M., Diele, K. in press. Litter processing and population food uptake of the mangrove crab Ucides cordatus in a high intertidal forest in north Brazil. Estuarine Coastal Shelf Science.

Nordi, N., 1994. A produção dos catadores de caranguejo-uçá (Ucides cordatus) na região de Várzea Nova, Paraíba, Brasil. Revista Nordestina de Biologia 9, 71-77.

O’Connor, N.J. and Epifanio, C.E., 1985. The effect of salinity on the dispersal and recruitment of fiddler crab larvae. Journal of Crustacean Biology 5, 137-145. 
Paula, J., Dray, T., Querioga, H., 2001. Interaction of off-shore and inshore processes controlling settlement of brachyuran megalopae in Saco mangrove creek, Inhaca Island (South Mozambique). Marine Ecology Progress Series 215, 251-260.

Rodriguez, M.D. and Hebling, N.J., 1989. Ucides cordatus cordatus (Linnaeus, 1763) (Crustacea, Decapoda). Complete larval development under laboratory conditions and its systematic position. Revista Brasileira de Zoologia 6, 147-166.

Sastry, A., 1983. Ecological aspects of reproduction. In: Vernberg, F., Vernberg, W. (Eds.), The biology of Crustacea, Environmental adaptations. Academic Press, New York, Vol. 8, pp. 179-270.

Scheltema, R.S., 1986. On dispersal and planktonic larvae of benthic invertebrates: an eclectic overview and summary of problems. Bulletin of Marine Science 39, 290-322.

Shanks, A.L., Grantham, B.A., Carr, M.H. 2003. Propagule dispersal distance and the size and spacing of marine reserves. Ecological Applications 13, Supplement, 159-169.

Türkay, M., 1970. Die Gecarcinidae Amerikas. Mit einem Anhang über Ucides Rathbun (Crustacea: Decapoda). Senckenbergiana Biologica 51, 333-354.

Underwood, A.J. and Fairweather, P.G., 1989. Supply-side ecology and benthic marine assemblages. Trends in Ecology and Evolution 4, 16-20.

Van Montfrans, J., Peery, C.A., Orth, R.J., 1990. Daily, monthly and annual settlement patterns by Callinectes sapidus and Neopanpoe sayi megalopae on artificial collectors deployed in the York River, Virginia: 1985-1988. Bulletin of Marine Science 46, 214-229. 
Van Montfrans, J., Epifanio, C.E., Knott, D.M., Lipicus, R.N., Mense, D.J., Metcalf, K.S., Olmi III, E.J., Orth, R.J., Posey, M.H., Wenner, E.L., West, T.L., 1995. Settlement of blue crab postlarvae in Western North Atlantic estuaries. Bulletin of Marine Science 57, 834-854.

\section{Figure Captures}

Figure 1. Location of the Caeté estuary and mangrove peninsula. White circles: Sampling stations for salinity measurements. FT (Furo do Taici), FO (Furo da Ostra), FC (Furo Chato) FG (Furo Grande): tidal creeks and channels; PA (Praia Ajuruteua): beach. Modified after Lará (2003).

Figure 2. Box-whisker plots for salinity measured at five sampling stations along the Caeté estuary during the wet season between 2001 and 2005 (PA: between 2002 and 2005) (pooled data). See Figure 1 for location of the measuring stations.

Figure 3. Number of study years with salinities $\leq 10$ during the weekly wet season sampling at five sampling stations along the Caeté estuary between 2001 and 2005 (PA: between 2002 and 2005). See Figure 1 for location of the measuring stations.

Figure 4. Survival of $U$. cordatus larvae from hatching to megalopa and for each zoeal stage $(\mathrm{ZI}-\mathrm{ZV})$ per salinity treatment $(\mathrm{n}$ initial $=50$ larvae per treatment, \% values of $\mathrm{ZII}-\mathrm{ZV}$ relate to decreasing $n$ values resulting from mortality in former stage). Equal letters indicate statistically homogeneous groups $(p>0.05)$.

Figure 5. Duration of development of $U$. cordatus larvae (average \pm 1 standard deviation) from hatching to megalopa and for each zoeal stage (ZI - ZV) per salinity treatment ( $\mathrm{n}$ initial $=50$ larvae per treatment, average duration of ZII to ZV stages relate to decreasing $n$ values 
resulting from mortality in former stage). Values without bars specify the time the larvae survived in a respective stage until dying without moulting to the next stage. Equal letters indicate statistically homogeneous groups ( $p>0.05)$.

Figure 6. Survival (\%) and development of $U$. cordatus larvae through successive zoeal stages in different salinities ( $\mathrm{n}$ initial = 50 larvae per treatment, \% values of subsequent stages relate to the initial $n=50$ ). Data are shown until day 27 when the last $Z V$ larva had moulted to megalopa. 